\title{
Maternal and neonatal vitamin $D$ status at birth in black South Africans
}

\author{
S C Velaphi, ${ }^{1} \mathrm{MB} \mathrm{ChB}, \mathrm{PhD} ; \mathbf{A}$ Izu, ${ }^{2} \mathrm{PhD} ; \mathbf{S}$ A Madhi, ${ }^{2,3} \mathrm{MB}$ BCh, PhD; J M Pettifor, ${ }^{4} \mathrm{MB}$ BCh, $\mathrm{PhD}$ \\ ${ }^{1}$ Department of Paediatrics, Faculty of Health Sciences, University of the Witwatersrand, Johannesburg, South Africa \\ ${ }^{2}$ Medical Research Council Respiratory and Meningeal Pathogens Research Unit, University of the Witwatersrand, Johannesburg, South Africa \\ ${ }^{3}$ Department of Science and Technology/National Research Foundation: Vaccine Preventable Diseases, University of the Witwatersrand, \\ Johannesburg, South Africa \\ ${ }^{4}$ SAMRC/Wits Developmental Pathways for Health Research Unit, Department of Paediatrics, Faculty of Health Sciences, University of the \\ Witwatersrand, Johannesburg, South Africa
}

Corresponding author: S C Velaphi (sithembiso.velaphi@wits.ac.za)

\begin{abstract}
Background. Vitamin D deficiency (VDD) in pregnant women has been associated with adverse pregnancy and neonatal outcomes. 25-hydroxyvitamin D (25(OH)D) levels are affected by numerous factors, including vitamin D intake, skin pigmentation, latitude and season of the year; they therefore vary by race and country. Vitamin D status in pregnant women and their offspring in South Africa (SA) is not well established.

Objectives. To assess vitamin D status by measuring serum 25(OH)D in pregnant black SA women and their offspring in Johannesburg (latitude $26^{\circ} \mathrm{S}$ ) and to assess whether vitamin D status is affected by maternal HIV infection.

Methods. We prospectively enrolled pregnant women and their healthy neonates, and measured 25(OH)D in maternal and cord blood at delivery. Pregnant women were stratified by their HIV status. Predictors of maternal and neonatal VDD (levels $<30 \mathrm{nmol} / \mathrm{L}$ ) were assessed using multiple logistic regression analysis.

Results. A total of 291 pregnant women and their healthy neonates were enrolled over a 21-month period. Mean (standard deviation) maternal and cord blood 25(OH)D levels were $57.0(29.7)$ and $41.9(21.0) \mathrm{nmol} / \mathrm{L}$ and the prevalence of VDD was $15.9 \%$ and $32.8 \%$, respectively. On average, concentrations of $25(\mathrm{OH}) \mathrm{D}$ in cord blood were $\sim 80 \%$ of those in the mother. There was no association between cord $25(\mathrm{OH}) \mathrm{D}$ and gestational age, but levels were associated with birth weight $(p<0.001)$. There were no differences in maternal or cord blood 25(OH)D levels between those HIV-infected or uninfected. The predictor of VDD in mothers was giving birth in winter (odds ratio (OR) 2.87, 95\% confidence interval (CI) 1.47 - 5.61), and in neonates the predictors were maternal age (OR 16.5, 95\% CI 1.82 - 149), being born in winter (OR 3.68, 95\% CI 2.05 - 6.61), being born by caesarean section (OR 4.92, 95\% CI 1.56 - 15.57) and being of low birth weight (OR 1.99, 95\% CI 1.13 - 3.50).

Conclusions. Among black SA women delivering in Johannesburg, about one in six mothers and one in three neonates have $25(\mathrm{OH}) \mathrm{D}$ levels indicative of VDD. Maternal HIV status appears not to affect levels of 25(OH)D in either the mother or her neonate. Research on the effects of VDD on the outcomes of pregnancy and the best methods to combat the high prevalence of VDD in women of childbearing age in the SA context is required.
\end{abstract}

S Afr Med J 2019;109(10):807-813. https://doi.org/10.7196/SAMJ.2019.v109i10.13651

Globally, women generally have poor vitamin D status during pregnancy. ${ }^{[1,2]}$ Maternal vitamin D deficiency (VDD) has been associated with an increased risk of adverse maternal and neonatal outcomes. ${ }^{[3]}$ The fetus is entirely dependent on transplacental acquisition of maternal 25-hydroxyvitamin D $(25(\mathrm{OH}) \mathrm{D})$ to maintain its vitamin $\mathrm{D}$ status, so neonatal vitamin $\mathrm{D}$ status at birth is directly related to maternal status. Vitamin D is a prohormone that is either ingested or produced in the skin from 7-dehydrocholesterol through the influence of ultraviolet B (UVB) radiation. Cholecalciferol (vitamin $\mathrm{D}_{3}$ ) and dietary vitamin $\mathrm{D}$ are transported to the liver, where they are metabolised to form $25(\mathrm{OH})$ $\mathrm{D}$, which is the major circulating vitamin $\mathrm{D}$ metabolite. $25(\mathrm{OH}) \mathrm{D}$ is converted in the kidney to 1,25 -dihydroxyvitamin $\mathrm{D}\left(1,25(\mathrm{OH})_{2} \mathrm{D}\right)$, the active form of vitamin D. $1,25(\mathrm{OH})_{2} \mathrm{D}$ binds to a single nuclear type 2 (vitamin $\mathrm{D}$ ) receptor to facilitate the activation or suppression of target genes. ${ }^{[4]}$

Serum 25(OH)D levels provide an excellent measure of overall vitamin $\mathrm{D}$ status. They reflect both intake from the diet and the amount contributed by skin synthesis. The levels are strongly associated with the degree of skin pigmentation and exposure to UVB radiation, which is influenced by skin coverage, latitude and season of the year. ${ }^{[5-7]}$ Rich sources of dietary vitamin D such as fortified foods, fish oil and organ meats are often not affordable to women from poor communities. In the absence of these dietary sources of vitamin D, sunlight therefore becomes the major source of vitamin D. In blacks, skin melanin decreases the penetration of UVB through the skin, limiting the production of vitamin $\mathrm{D}$. The high melanin content of the skin and an inadequate intake of dietary vitamin D could therefore put black women at risk of developing VDD. Other strong determinants of serum 25(OH)D levels are latitude and the season of the year. Serum $25(\mathrm{OH}) \mathrm{D}$ levels are higher during summer than winter months and in populations closer to the equator. However, these responses are also influenced by genetic factors, duration and dose of UVB exposure, and baseline serum 25(OH)D levels. ${ }^{[8,9]}$ It is therefore important to report levels of 25(OH)D for different communities based on skin pigmentation, latitude and seasons of the year. 


\section{Objectives}

Levels of 25(OH)D in pregnant mothers and their offspring have not been well studied in sub-Saharan Africa, especially in settings where the majority of pregnant women are black and women frequently have HIV infection. HIV infection could potentially affect the transfer of $25(\mathrm{OH}) \mathrm{D}$ through altering maternal-fetal exchange. ${ }^{[10]}$ It is therefore important to determine the prevalence of VDD in neonates, not only in segments of the population in which VDD is likely to be high, but also in settings where the prevalence of HIV is high. The objectives of this study were to determine the 25(OH)D levels of pregnant women and their infants at birth and to assess whether levels are affected by maternal HIV status.

\section{Methods}

\section{Study design and setting}

We undertook a prospective cohort study at Chris Hani Baragwanath Academic Hospital (CHBAH) in Soweto, Johannesburg, South Africa (SA), between March 2013 and November 2014. Soweto has a latitude of $26^{\circ} \mathrm{S}$, an average elevation of $1600 \mathrm{~m}$ and a temperate climate. The average daily sunshine hours vary between 7 hours 30 minutes and 9 hours 45 minutes over the year. All pregnant women attending antenatal care at CHBAH are counselled and offered HIV testing as part of standard care. The HIV prevalence has been 29\% since 2006. ${ }^{[1]}$

\section{Study population and procedures}

All mothers and their neonates who were delivered at $\mathrm{CHBAH}$ during weekdays between $08 \mathrm{~h} 00$ and $14 \mathrm{~h} 00$ were eligible for the study. Neonates who had major congenital abnormalities, were assessed to have clinical signs of infection or had been prescribed antibiotics by the attending doctor were excluded. Only those whose mothers had consented were enrolled. Selection of patients was based on a convenience sample; the first two consenting mothers screened between $08 \mathrm{~h} 00$ and $14 \mathrm{~h} 00$ on weekdays who delivered neonates meeting the inclusion criteria were enrolled. Following informed consent from mothers, blood was collected from the mother and the umbilical cord of her neonate. Blood samples were centrifuged at $2000 \mathrm{~g}$ for 5 minutes and separated serum was refrigerated at $-70^{\circ} \mathrm{C}$ until the assays were performed at the end of enrolment. 25(OH)D levels were measured in both maternal and cord blood samples.

\section{Data collection}

The maternal data collected included race, age, gravidity, HIV status, and mode and month of delivery, and the neonatal data included birth weight, gestational age, Apgar score and health status. 25(OH)D levels were measured using the Liaison chemiluminescent immunoassay (DiaSorin, Italy). The inter-assay coefficient of variation (CV) for lower and higher controls was $10 \%$ and $9 \%$, respectively, and the intra-assay $\mathrm{CV}$ was $8 \%$ and $6 \%$, respectively. VDD was defined as a $25(\mathrm{OH}) \mathrm{D}$ concentration of $<30 \mathrm{nmol} / \mathrm{L}^{.[12]}$ To assess seasonal variation in $25(\mathrm{OH}) \mathrm{D}$ concentrations, the seasons were divided as follows: summer (December through February), autumn (March through May), winter (June through August) and spring (September through November).

\section{Sample size estimation}

As a prospective survey to assess vitamin D status, we estimated that we needed to enrol a cohort of 320 pregnant women. This was based on a prevalence of VDD $(25(\mathrm{OH}) \mathrm{D}<30 \mathrm{nmol} / \mathrm{L})$ of $3.4 \%$ reported in an abstract from a pilot study conducted in pregnant women delivering at $\mathrm{CHBAH},{ }^{[13]}$ and having $2 \%$ confidence limits and a $95 \%$ confidence level.

\section{Data analysis}

In order to assess the relationship between 25(OH)D levels and HIV status, mothers were stratified into HIV-negative and HIVpositive, and infants into HIV-unexposed and HIV-exposed (but not necessarily infected). Infants were grouped according to gestational age $(<30,30-34,35-37$ and $>37$ weeks) and weight $(<1500,1500-$ $1999,2000-2499$ and $\geq 2500$ g) categories. Correlations between cord blood and maternal 25(OH)D concentrations were assessed using the Pearson test. Multivariate logistic regression analyses were performed to determine factors associated with VDD.

\section{Ethical considerations}

Ethics approval to conduct the study was obtained from the University of the Witwatersrand Human Research Ethics Committee (ref. no. M120651), and the management of the hospital gave its approval. Written informed consent for study inclusion was obtained from the mothers for themselves and their newborns.

\section{Results}

\section{Study population}

Out of a total of 6179 deliveries conducted between $08 \mathrm{~h} 00$ and $14 \mathrm{~h} 00$ on weekdays over a 21 -month period, a total of 696 pregnant women were approached for informed consent, with 75 (10.8\%) refusing consent. Neonates of 276 mothers were assessed to be sick by the attending doctor and were therefore excluded. A total of 345 mothers with 360 well neonates were enrolled, and 291 mothers and neonates were included in the final analysis (Fig. 1). Neonates who were enrolled on the same day after the first two neonates had been enrolled were excluded ( $n=69)$. There were more women enrolled during the autumn and winter months than other months, as the enrolment period was 21 months which included two autumn, winter and spring seasons, and there was slow enrolment towards the end of the study because we lost the services of our research assistant.

\section{Maternal characteristics}

Maternal HIV status was known for all but one mother, and 138 (47\%) were HIV-positive. The majority of the neonates (98\%) were

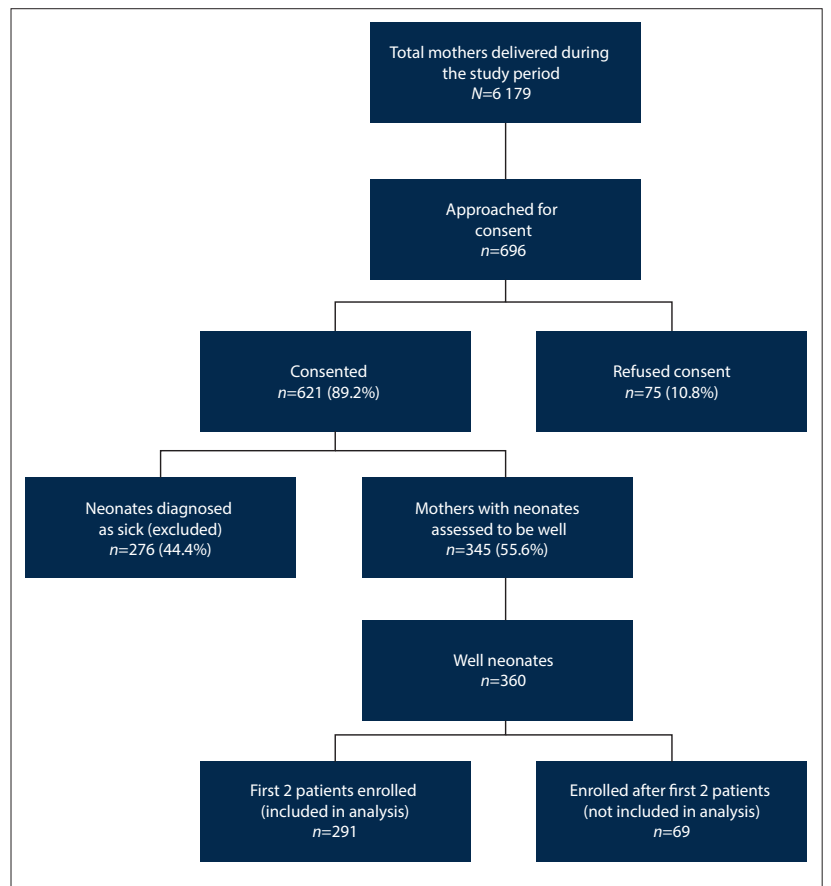

Fig. 1. Mothers and neonates enrolled in the study. 
born to black African women, with a mean (standard deviation (SD)) age of 28 (6) years; $70 \%$ were multiparous and $94 \%$ delivered vaginally (Table 1). There was no association between demographic variables and HIV status except for maternal age, which on average was 4 years younger in HIV-negative mothers than in HIV-positive mothers.

\section{5( $\mathrm{OH}) \mathrm{D}$ levels in pregnant women}

The mean (SD) $25(\mathrm{OH}) \mathrm{D}$ concentration in pregnant women was 57.0 (29.7) nmol/L. There were no statistical significant differences in $25(\mathrm{OH}) \mathrm{D}$ levels between HIV-positive and negative mothers (58.8 (31.2) v. 55.5 (28.3) nmol/L, respectively; $p>0.05$ ) (Table 2). Maternal levels of $25(\mathrm{OH}) \mathrm{D}$ did not differ by duration of gestation or neonatal birth weight. Maternal levels were also not associated with HIV status even after adjusting for gestational age $(p=0.410)$. VDD (serum $25(\mathrm{OH}) \mathrm{D}<30 \mathrm{nmol} / \mathrm{L})$ was present in $16 \%$ of mothers.

\section{5(OH)D levels in cord blood}

The mean cord blood 25(OH)D level (SD) was 41.9 (21.0) nmol/L, and there was no statistically significant difference between HIVexposed and unexposed neonates (40.7 (21.2) v. 42.8 (20.9) nmol/l; $p=0.172$ ) (Table 2). VDD was noted in $33 \%$ of neonates overall. There was no statistically significant difference in the prevalence of neonates with $25(\mathrm{OH}) \mathrm{D}$ deficiency among the HIV-exposed and unexposed mothers (36.2\% v. $29.8 \%$; $p=0.129)$, even after stratifying them into preterm ( $\leq 37$ weeks) and term ( $>37$ weeks), or into low birth weight $(<2500 \mathrm{~g})$ and normal birth weight $(\geq 2500 \mathrm{~g})$.

\section{Transplacental transfer of $25(\mathrm{OH}) \mathrm{D}$}

On average, concentrations of $25(\mathrm{OH}) \mathrm{D}$ in cord blood were $\sim 80 \%$ (mean (SD) cord-to-maternal 25(OH)D ratio $0.79(0.45)$ ) of those in the mothers (Table 3). There was no association between the fraction of $25(\mathrm{OH}) \mathrm{D}$ transferred and gestational age or maternal HIV status. However, the fraction increased significantly as birth weight increased $(p<0.001)$. On average, the ratio increased by $30 \%$ for every $1000 \mathrm{~g}$ increase in birth weight. There was a significant correlation between maternal and cord serum 25(OH)D levels with $r=0.53$ (Fig. 2), and there was a strong association between VDD in mother and infant $(p<0.001)$.

\section{$25(\mathrm{OH}) \mathrm{D}$ levels in relation to the season of the year}

Mean 25(OH)D levels were highest in summer and lowest in winter for both mothers and their infants (Fig. 3). The proportion of mothers with VDD increased from $7 \%$ in summer to $27 \%$ in winter, while the prevalence of VDD in cord blood increased from $22 \%$ in summer to $60 \%$ in winter. Pregnant women were three times more

Table 1. Characteristics of enrolled mothers and their healthy neonates

\begin{tabular}{|c|c|c|c|c|}
\hline & Overall $\left(N=291^{*}\right)$ & HIV-positive $(N=138)$ & HIV-negative $(N=152)$ & $p$-value \\
\hline \multicolumn{5}{|l|}{ Maternal characteristics } \\
\hline Black African, $n(\%)$ & $286(98.3)$ & $137(99.3)$ & $149(97.4)$ & 0.427 \\
\hline Maternal age (years), mean (SD) & $28(6)$ & $30(6)$ & $26(6)$ & $<0.001$ \\
\hline Gravidity, $n(\%)$ & & & & 0.127 \\
\hline 1 & $86(29.6)$ & $33(23.9)$ & $52(34.2)$ & \\
\hline $2-4$ & $188(64.6)$ & $95(68.8)$ & $93(61.2)$ & \\
\hline$>4$ & $17(5.8)$ & $10(7.2)$ & $7(4.6)$ & \\
\hline Mode of delivery, $n(\%)$ & & & & 0.314 \\
\hline Vaginal & $273(93.8)$ & $132(95.7)$ & $140(92.1)$ & \\
\hline Caesarean section & $18(6.2)$ & $6(4.3)$ & $12(7.9)$ & \\
\hline Season of the year at birth, $n(\%)$ & & & & 0.267 \\
\hline Autumn & $113(38.8)$ & $47(34.1)$ & $66(43.4)$ & \\
\hline Winter & $73(25.1)$ & $36(26.1)$ & $37(24.3)$ & \\
\hline Spring & $57(19.6)$ & $27(19.6)$ & $29(19.1)$ & \\
\hline Summer & $48(16.5)$ & $28(20.3)$ & $20(13.2)$ & \\
\hline \multicolumn{5}{|l|}{ Infant characteristics } \\
\hline Birth weight (g), mean (SD) & $2819(544)$ & $2815(527)$ & $2824(562)$ & 0.88 \\
\hline Birth weight categories (g), $n(\%)$ & & & & 0.795 \\
\hline$<1500$ & 0 & 0 & 0 & \\
\hline $1500-1999$ & $15(5.2)$ & $6(4.3)$ & $9(5.9)$ & \\
\hline $2000-2499$ & $84(28.9)$ & $41(29.7)$ & $42(27.6)$ & \\
\hline$\geq 2500$ & $192(66)$ & $91(65.9)$ & $101(66.4)$ & \\
\hline Gestational age (weeks), mean (SD) & $37(2)$ & $37(2)$ & $37(2)$ & 0.731 \\
\hline Gestational age categories (weeks), $n(\%)$ & & & & 0.99 \\
\hline$<30$ & $2(0.7)$ & $1(0.7)$ & $1(0.7)$ & \\
\hline $30-34$ & $40(13.7)$ & $19(13.8)$ & $20(13.2)$ & \\
\hline $35-37$ & $101(34.7)$ & $49(35.5)$ & $52(34.2)$ & \\
\hline$>37$ & $148(50.9)$ & $69(50.0)$ & $79(52.0)$ & \\
\hline \multicolumn{5}{|l|}{ Apgar score, median (IQR) } \\
\hline 1 minute & $9(9-9)$ & $9(9-9)$ & $9(9-9)$ & 0.912 \\
\hline 5 minutes & $10(10-10)$ & $10(10-10)$ & $10(10-10)$ & 0.965 \\
\hline
\end{tabular}


Table 2. Levels of 25(OH)D in maternal and cord blood

\begin{tabular}{|c|c|c|c|c|c|c|}
\hline & \multicolumn{3}{|c|}{ Serum $25(\mathrm{OH}) \mathrm{D}$ concentrations $(\mathrm{nmol} / \mathrm{L})$, mean $(\mathrm{SD})$} & \multicolumn{3}{|c|}{ Proportion with VDD, $n / N(\%)$} \\
\hline & $\begin{array}{l}\text { HIV-infected } \\
(N=138)\end{array}$ & $\begin{array}{l}\text { HIV-uninfected } \\
(N=152)\end{array}$ & All $\left(N=291^{*}\right)$ & $\begin{array}{l}\text { HIV-infected } \\
(N=138)\end{array}$ & $\begin{array}{l}\text { HIV-uninfected } \\
(N=152)\end{array}$ & All $\left(N=291^{\star}\right)$ \\
\hline \multicolumn{7}{|l|}{ Maternal } \\
\hline All & $58.8(31.2)$ & $55.5(28.3)$ & $57.0(29.7)$ & 23/137 (16.8) & $23 / 152(15.1)$ & $46 / 290(15.9)$ \\
\hline \multicolumn{7}{|c|}{ Gestational age (weeks) } \\
\hline$<30$ & $31.8(\mathrm{n} / \mathrm{a})$ & $71.5(\mathrm{n} / \mathrm{a})$ & $51.6(28.1)$ & $0 / 1(0)$ & $0 / 1(0)$ & $0 / 2(0)$ \\
\hline $30-34$ & $54.3(32.8)$ & $46.2(21.8)$ & $49.9(27.1)$ & $3 / 18(16.7)$ & $4 / 20(20.0)$ & $7 / 39(17.9)$ \\
\hline $35-37$ & $57.1(34.2)$ & $52.2(26.7)$ & $54.6(30.5)$ & 9/49 (18.4) & $11 / 52(21.2)$ & 20/101 (19.8) \\
\hline$>37$ & $61.5(28.8)$ & $59.9(30.3)$ & $60.7(29.5)$ & $11 / 69(15.9)$ & $8 / 79(10.1)$ & $19 / 148(12.8)$ \\
\hline \multicolumn{7}{|l|}{ Season } \\
\hline Autumn & $59.3(26.1)$ & $55.4(23.5)$ & $57.0(24.5)$ & 9/46 (19.6) & $5 / 66(7.6)$ & $14 / 112(12.5)$ \\
\hline Winter & $41.2(20.1)$ & $43.5(17.6)$ & $42.4(18.8)$ & $12 / 36(33.3)$ & $8 / 37(21.6)$ & $20 / 73(27.4)$ \\
\hline Spring & $59.9(33.9)$ & $55.2(34.4)$ & $57.3(33.7)$ & $0 / 27(0)$ & $9 / 29(31)$ & 9/57 (15.8) \\
\hline Summer & $79.2(35.8)$ & $78.6(36.4)$ & $79.0(35.7)$ & $2 / 28(7.1)$ & $1 / 20(5)$ & $3 / 48(6.2)$ \\
\hline \multicolumn{7}{|l|}{ Cord blood } \\
\hline All & $40.7(21.2)$ & $42.8(20.9)$ & $41.9(21.0)$ & $50 / 138(36.2)$ & $45 / 151(29.8)$ & $95 / 290(32.8)$ \\
\hline \multicolumn{7}{|c|}{ Gestational age (weeks) } \\
\hline$<30$ & $13.8(\mathrm{n} / \mathrm{a})$ & $27.8(\mathrm{n} / \mathrm{a})$ & $20.8(9.8)$ & $1 / 1(100)$ & $1 / 1(100)$ & $2 / 2(100)$ \\
\hline $30-34$ & $47.2(29.6)$ & $34.0(17.2)$ & $41.1(24.8)$ & $7 / 19(36.8)$ & $9 / 20(45.0)$ & $16 / 40(40.0)$ \\
\hline $35-37$ & $36.7(18.3)$ & $42.5(22.7)$ & $39.7(20.8)$ & $19 / 49(38.8)$ & $19 / 52(36.5)$ & $38 / 101(37.6)$ \\
\hline$>37$ & $42.2(20.0)$ & $45.3(20.2)$ & $43.9(20.1)$ & 23/69 (33.3) & $16 / 78(20.5)$ & $39 / 147(26.5)$ \\
\hline \multicolumn{7}{|c|}{ Birth weight categories (g) } \\
\hline$<1500$ & - & - & - & - & - & - \\
\hline $1500-1999$ & $38.8(25.5)$ & $30.7(17.3)$ & $34.0(20.5)$ & $3 / 6(50.0)$ & $6 / 9(66.7)$ & $9 / 15(60.0)$ \\
\hline $2000-2499$ & $39.4(24.6)$ & $37.8(22.8)$ & $38.9(23.7)$ & $17 / 41(41.5)$ & $19 / 41(46.3)$ & $36 / 83(43.4)$ \\
\hline$\geq 2500$ & $41.4(19.4)$ & $45.8(19.7)$ & $43.8(19.7)$ & $30 / 91(33.0)$ & $20 / 101(19.8)$ & $50 / 192(26.0)$ \\
\hline \multicolumn{7}{|l|}{ Season } \\
\hline Autumn & $45.6(18.5)$ & $49.8(20.2)$ & $48.1(19.5)$ & 9/47 (19.1) & $10 / 66(15.2)$ & 19/113 (16.8) \\
\hline Winter & $30.1(19.2)$ & $34.3(16.0)$ & $32.2(17.6)$ & $22 / 36(61.1)$ & $18 / 37(48.6)$ & 40/73 (54.8) \\
\hline Spring & $39.0(19.6)$ & $33.3(18.7)$ & $36.7(19.5)$ & $12 / 27(44.4)$ & $13 / 28(46.4)$ & $25 / 56(44.6)$ \\
\hline Summer & $47.8(24.6)$ & $48.3(24.4)$ & $48.0(24.2)$ & $7 / 28(25.0)$ & $4 / 20(20.0)$ & $11 / 48$ (22.9) \\
\hline
\end{tabular}

Table 3. Serum 25(OH)D cord-to-mother ratio

\begin{tabular}{|c|c|c|c|}
\hline & HIV-infected ( $N=138)$, mean $(S D)$ & HIV-uninfected $(N=152)$, mean (SD) & Overall $\left(N=291^{*}\right)$, mean $(S D)$ \\
\hline All & $0.77(0.42)$ & $0.85(0.42)$ & $0.82(0.42)$ \\
\hline \multicolumn{4}{|c|}{ Gestational age categories (weeks) } \\
\hline$<30$ & $0.44(\mathrm{n} / \mathrm{a})$ & $0.39(\mathrm{n} / \mathrm{a})$ & $0.41(0.03)$ \\
\hline $30-34$ & $0.92(0.62)$ & $0.78(0.33)$ & $0.86(0.49)$ \\
\hline $35-37$ & $0.75(0.40)$ & $0.86(0.33)$ & $0.81(0.37)$ \\
\hline$>37$ & $0.75(0.36)$ & $0.87(0.49)$ & $0.82(0.44)$ \\
\hline \multicolumn{4}{|c|}{ Birth weight categories (g) } \\
\hline$<1500$ & - & - & - \\
\hline $1500-1999$ & $0.60(0.24)$ & $0.65(0.20)$ & $0.63(0.21)$ \\
\hline $2000-2499$ & $0.77(0.48)$ & $0.75(0.39)$ & $0.77(0.44)$ \\
\hline$\geq 2500$ & $0.78(0.40)$ & $0.91(0.44)$ & $0.85(0.42)$ \\
\hline
\end{tabular}

likely to be vitamin D deficient if delivered in winter compared with the other seasons.

\section{Factors associated with VDD in cord blood}

On multiple regression analysis, the predictor of VDD in pregnant women at the time of delivery was giving birth during winter (odds ratio (OR) OR 2.87, 95\% confidence interval (CI) CI 1.47 - 5.61) (Table 4). The predictors of VDD in cord blood were maternal age $>20$ years (OR 16.5, 95\% CI 1.82 - 149.0; $p=0.013$ ), delivery in winter (OR 3.68, 95\% CI $2.05-6.61 ; p<0.001$ ), low birth weight (OR 1.99, $95 \%$ CI $1.13-3.50 ; p=0.017)$ and being born by caesarean section (OR 4.92, 95\% CI $1.56-5.57 ; p=0.003$ ) (Table 5). 


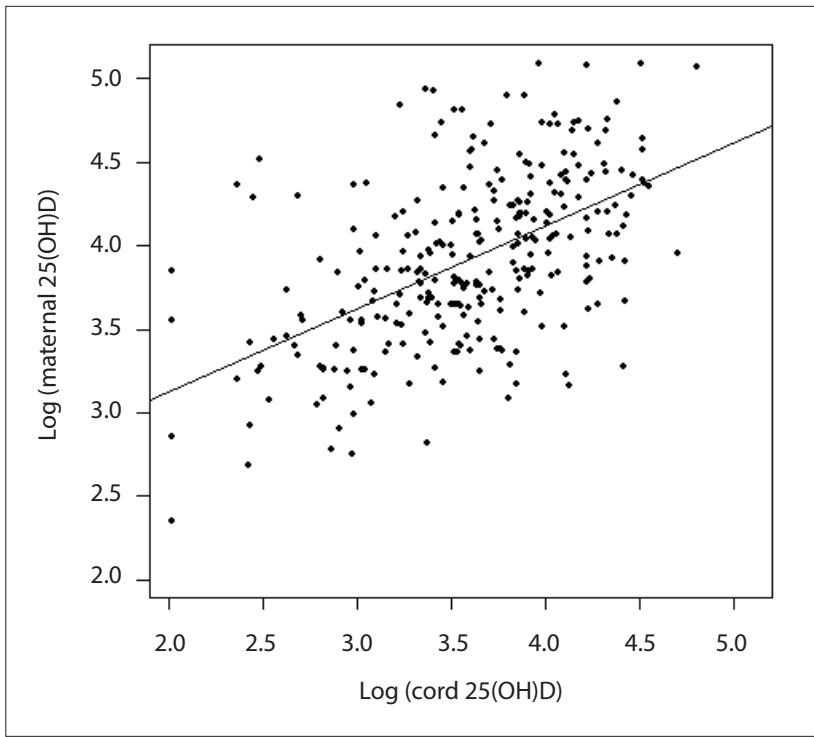

Fig. 2. Correlation between maternal and cord blood 25(OH)D concentrations $(\mathrm{r}=0.53, \mathrm{p}<0.001) .(25(\mathrm{OH}) \mathrm{D}=25$-hydroxyvitamin $\mathrm{D}$.)

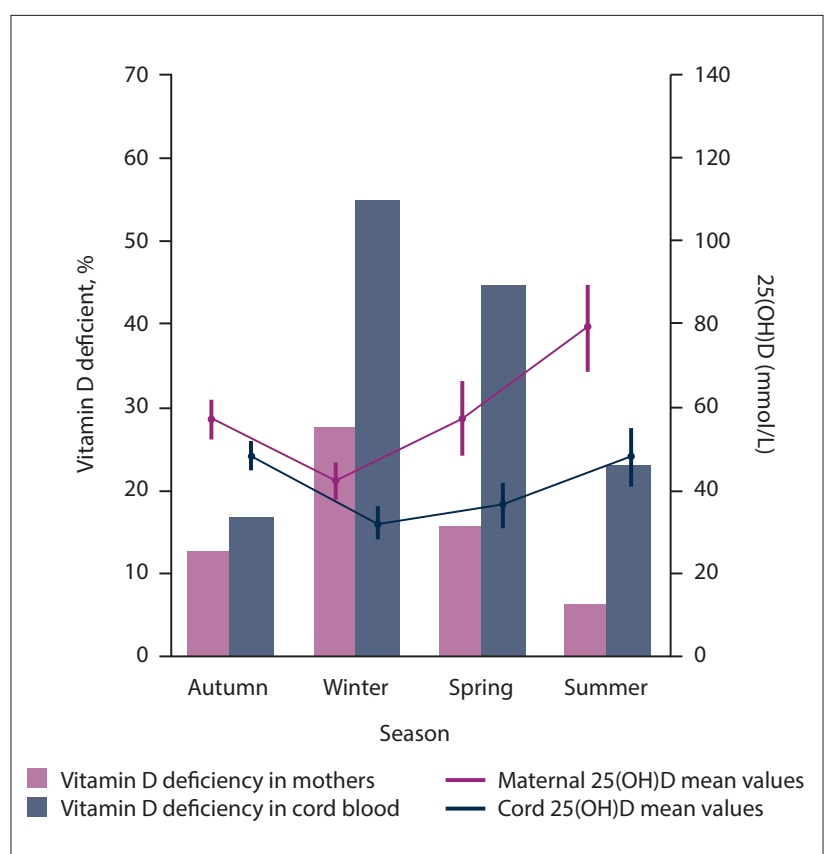

Fig. 3. Maternal and cord blood 25(OH)D levels according to different seasons of the year. $(25(\mathrm{OH}) \mathrm{D}=25$-hydroxyvitamin D.)

\section{Discussion}

The increasing number of reports of VDD being associated with adverse obstetric and neonatal outcomes suggests that the extent of this problem should be assessed for each community or population in which VDD may be prevalent. Serum $25(\mathrm{OH})$ D reflects the adequacy of vitamin $\mathrm{D}$ intake and cutaneous production and is therefore used for assessment of vitamin D status. In this study, we assessed serum 25(OH)D in women and their offspring at delivery in Johannesburg, SA (latitude $26^{\circ} \mathrm{S}$ ), throughout the year in order to assess the prevalence of VDD and the factors associated with this deficiency.

In a cohort of 291 pregnant women, we found that the mean (SD) $25(\mathrm{OH}) \mathrm{D}$ level was $57.0(29.7) \mathrm{nmol} / \mathrm{L}$, and that about one in six pregnant women $(16 \%)$ were vitamin $\mathrm{D}$ deficient at delivery. The maternal serum $25(\mathrm{OH}) \mathrm{D}$ levels in this study were similar to those reported in non-pregnant adult black African women in Johannesburg, in whom the mean $25(\mathrm{OH}) \mathrm{D}$ level was $58.3 \mathrm{nmol} / \mathrm{L},{ }^{[14]}$ and to levels reported in African Americans in the USA, ${ }^{[15-17]}$ but higher than those reported from Asian countries, where the mean is $<40 \mathrm{nmol} / \mathrm{L} \cdot{ }^{[18]}$ Compared with studies in other parts of sub-Saharan Africa, the mean value in the present study was lower. ${ }^{[19-22]}$ In Nigeria, the mean 25(OH)D level was reported to be $90 \mathrm{nmol} / \mathrm{L}$ in pregnant women not practising purdah (use of veils by women). ${ }^{[19]}$ In East Africa, mean serum 25(OH)D levels in pregnant women ranged from $91.9 \mathrm{nmol} / \mathrm{L}$ in rural western Kenya ${ }^{[22]}$ to $141.9 \mathrm{nmol} / \mathrm{L}$ and $147.7 \mathrm{nmol} / \mathrm{L}$ in the Sengerema and Maasai ethnic groups, respectively. ${ }^{[20]}$ Likely reasons for these geographical differences are related to differences in sun exposure and its zenith angle, but they could also be due to the different methodologies used to determine $25(\mathrm{OH}) \mathrm{D}$.

In the present study, it was also noted that levels of $25(\mathrm{OH}) \mathrm{D}$ varied by season, with levels during summer being almost double those in winter $(82.9 \mathrm{v} .41 .8 \mathrm{nmol} / \mathrm{L})$. Not surprisingly, the prevalence of VDD among mothers also varied seasonally, with VDD being four times more common in winter than in summer $(27 \%$ v. $7 \%)$. Numerous other studies have reported similar seasonal variations. ${ }^{[23-26]}$ The present study and these other studies confirm that sun exposure is a major determinant of vitamin D status in humans. The proportion of women with deficiency in this study was much higher than that reported in a pilot study from the same institution (Ranchod et al. ${ }^{[13]}$ ), where deficiency was noted in only $3.4 \%$ of women. The reasons for this difference are unclear, but it may be due to fewer women being studied, and the data only being collected in autumn, despite this being one of the seasons when $25(\mathrm{OH}) \mathrm{D}$ levels are expected to be high.

The mean 25(OH)D concentration in cord blood was $41.9 \mathrm{nmol} / \mathrm{L}$, and it correlated with maternal serum $25(\mathrm{OH}) \mathrm{D}$ concentrations $(r=0.53)$. This finding is similar to other studies that have consistently reported a correlation between cord blood $25(\mathrm{OH}) \mathrm{D}$ and maternal concentrations. ${ }^{[15,17,23,27-29]}$ Although the correlation of $r=0.53$ is similar to that reported by Yu et al. ${ }^{[30]}$ in the UK $(r=0.45)$ and higher than that reported by Thomas et al. ${ }^{[27]}$ from New Zealand $(r=0.30)$, it is lower than those in many other studies, which reported correlations ranging from 0.63 to $0.89 .{ }^{[15,17,23,29]}$ The main factors influencing cord blood concentrations of 25(OH)D in the present study were maternal serum $25(\mathrm{OH}) \mathrm{D}$, season of the year, low birth weight and caesarean section.

Overall, the prevalence of VDD in neonates was $~ 33 \%$. This prevalence is lower than that reported in African-American neonates, which varied from $46 \%$ to $65 \% .^{[15,31-33]}$ The prevalence in white neonates has been reported to be much lower at $4-11 \%{ }^{[15,31,34,35]}$ These variations between racial groups reflect differences in $25(\mathrm{OH})$ $\mathrm{D}$ levels between black and white mothers. In our study, the ratio of cord to maternal $25(\mathrm{OH}) \mathrm{D}$ improved with increasing birth weight, suggesting a role for placental function maturity in the transfer of $25(\mathrm{OH}) \mathrm{D}$, levels of fetal vitamin D-binding protein or changes in fetal rates of hydroxylation or catabolism. Higher maternal $25(\mathrm{OH})$ D levels have previously been shown to be significantly associated with higher placental volume, ${ }^{[36]}$ and vitamin $\mathrm{D}$ insufficiency has been associated with low birth weight. ${ }^{[37,38]}$ It is unclear why neonates born by caesarean section were more likely to have VDD, despite adjustment for seasons. Possible reasons could be related to the indication for caesarean section. In our study setting, one of the common indications for caesarean section is pre-eclampsia, the prevalence of which has been associated with VDD. ${ }^{[39-41]}$ The low 


\begin{tabular}{|c|c|c|c|c|}
\hline Variable & $n(\%)$ & Univariate $p$-value & OR $(95 \% \mathrm{CI})$ & Multivariate $p$-value \\
\hline \multicolumn{5}{|l|}{ Maternal age (years) } \\
\hline$<20$ & $23(7.9)$ & Ref & - & - \\
\hline $20-35$ & $228(78.4)$ & 0.684 & - & - \\
\hline$>35$ & $40(13.7)$ & 0.862 & - & - \\
\hline Mother black African & $286(98.3)$ & 0.989 & - & - \\
\hline Mother primigravida & $86(29.6)$ & 0.375 & - & - \\
\hline Mother HIV-infected & $138(47.6)$ & 0.701 & - & - \\
\hline Delivered in winter months & $73(25.1)$ & 0.002 & $2.87(1.47-5.61)$ & 0.002 \\
\hline Preterm (<37 weeks) & $104(35.7)$ & 0.91 & $0.54(0.24-1.26)$ & 0.156 \\
\hline Low birth weight (<2 $500 \mathrm{~g})$ & $99(34.0)$ & 0.148 & $2.18(0.97-4.9)$ & 0.058 \\
\hline Caesarean section & $18(6.2)$ & 0.923 & - & - \\
\hline
\end{tabular}

\begin{tabular}{|c|c|c|c|}
\hline Variable & Univariate $p$-value & OR $(95 \% \mathrm{CI})$ & Multivariate $p$-value \\
\hline \multicolumn{4}{|l|}{ Maternal age (years) } \\
\hline$<20$ & & Ref & Ref \\
\hline $20-35$ & 0.012 & $16.48(1.82-148.97)$ & 0.013 \\
\hline$>35$ & 0.089 & $9.13(0.9-92.93)$ & 0.062 \\
\hline Mother black African & 0.729 & - & - \\
\hline Mother primigravida & 0.748 & - & - \\
\hline Mother HIV-infected & 0.246 & - & - \\
\hline Delivered in winter months & $<0.001$ & $3.68(2.05-6.61)$ & $<0.001$ \\
\hline Preterm (<37 weeks) & 0.123 & - & - \\
\hline Low birth weight (<2 $500 \mathrm{~g}$ ) & 0.001 & $1.99(1.13-3.5)$ & 0.017 \\
\hline Caesarean section & 0.003 & $4.92(1.56-15.57)$ & 0.007 \\
\hline
\end{tabular}

rate of caesarean section in this cohort is probably due to the cases of caesarean section being selected out because of the enrolment process, as enrolment took place soon after delivery, when neonates delivered by caesarean section were likely to be receiving specialised care and attention in resuscitation areas.

The higher than expected proportion of HIV-infected women in the cohort $(41 \%$ v. $29 \%$ among all women delivering at the hospital) is the most likely reason for the higher proportion of low-birth-weight infants in the study than in the overall hospital delivery population. HIV infection in pregnancy is associated with an increased prevalence of low-birth-weight infants. ${ }^{[42]}$ HIV infection has been associated with VDD in a number of studies. ${ }^{[43-47]}$ This association has been explained by possibly reduced maternal sunlight exposure owing to severity of the infection, or increased susceptibility of HIV infection due to VDDassociated immunosuppression. Treatment with antiretrovirals has been reported to improve $25(\mathrm{OH}) \mathrm{D}$ levels. ${ }^{[48,49]}$ In the present study, we did not find any association between HIV infection and VDD, possibly because most HIV-infected mothers were on antiretroviral therapy and well.

\section{Study strengths and limitations}

The strengths of this study include the large number of patients enrolled and the fact that the study was conducted across the four seasons of the year. Further, the laboratory that measured the $25(\mathrm{OH}) \mathrm{D}$ levels has participated for many years in an external quality assurance programme (DEQAS) that monitors the accuracy of the assay used. A limitation of this study is that environmental and nutritional factors such as the use of vitamin D supplements, sunscreens and sunlight exposure, which could influence vitamin D status, were not assessed.

\section{Conclusions}

The present study has highlighted the generally poor vitamin D status of black women and their neonates delivering at $\mathrm{CHBAH}$, with one in six women and one in three neonates being VDD. A marked seasonal variation in $25(\mathrm{OH}) \mathrm{D}$ levels in both the mothers and their neonates was noted, indicating the importance of the contribution of sunlight exposure and epidermal synthesis of vitamin D in the mother in maintaining vitamin $\mathrm{D}$ status. These data raise concerns about the lack of a policy in SA recommending routine vitamin D supplementation of black mothers during pregnancy, as has been proposed in an international consensus statement and by the Institute of Medicine. ${ }^{[12,50]}$ Although no data are available on the consequences of VDD during pregnancy and lactation on mothers and their infants in SA, there is a growing body of international literature to suggest that low vitamin D status may have effects on pregnancyinduced hypertension, preterm deliveries, fetal growth and birth weight, neonatal bone mass, risk of asthma, neonatal hypocalcaemia and epigenetics. ${ }^{[51]}$ Future studies should investigate the factors influencing vitamin $\mathrm{D}$ status in mothers and their offspring, the maternal and fetal/neonatal outcomes associated with poor vitamin D status, and the most efficacious way of correcting maternal VDD through supplementation during pregnancy. 
Declaration. This study was part of the work towards SCV's PhD degree. Acknowledgements. Thanks to the research nurse, Ms Beauty Modau, who assisted us with data collection, and Yusuf Guman, who assisted with laboratory analysis.

Author contributions. SCV: study conceptualisation, study design, collection of data, data analysis and interpretation, drafted and revised manuscript, approved submission of manuscript. AI: statistical data analysis and interpretation, revised and reviewed manuscript, approved submission of manuscript. SAM: study design, data interpretation, revised and reviewed manuscript, approved submission of manuscript. JMP: study conceptualisation, study design, data interpretation, revised and reviewed manuscript, approved submission of manuscript.

Funding. The study was funded by the South African Medical Research Council.

Conflicts of interest. None.

1. Goswami R, Gupta N, Goswami D, Marwaha RK, Tandon N, Kochupillai N. Prevalence and significance of low 25-hydroxyvitamin D concentrations in healthy subjects in Delhi. Am J Clin Nutr 2000;72(2):472475. https://doi.org/10.1093/ajcn/72.2.472

2. Sachan A, Gupta R, Das V, Agarwal A, Awasthi PK, Bhatia V. High prevalence of vitamin D deficiency among pregnant women and their newborns in northern India. Am J Clin Nutr 2005;81(5):1060-1064. https://doi.org/10.1093/ajcn/81.5.106

3. Van der Pligt P, Willcox J, Szymlek-Gay EA, Murray E, Worsley A, Daly RM. Associations of maternal vitamin D deficiency with pregnancy and neonatal complications in developing countries: A systematic review. Nutrients 2018;10(5):640. https://doi.org/10.3390/nu10050640

4. DeLuca HF. Overview of general physiologic features and functions of vitamin D. Am J Clin Nutr 2004;80(6 Suppl):1689S-1696S. https://doi.org/10.1093/ajcn/80.6.1689S

5. Rapuri PB, Kinyamu HK, Gallagher JC, Haynatzka V. Seasonal changes in calciotropic hormones, bone . Rapuri PB, Kinyamu HK, Gallagher C, Haynatzka V. Seasonal changes in calciotropic hormones, bone
markers, and bone mineral density in elderly women. J Clin Endocrinol Metab 2002;87(5):2024-2032. markers, and bone mineral density in eldet
https://doi.org/10.1210/jcem.87.5.8475

6. Armas LA, Dowell S, Akhter M, et al. Ultraviolet-B radiation increases serum 25-hydroxyvitamin D levels: The effect of UVB dose and skin color. J Am Acad Dermatol 2007;57(4):588-593. https://doi. org/10.1016/j.jaad.2007.03.004

Tull M Jr, Kallikorm R, Tamm A, Lember M. Seasonal variance of 25-(OH) vitamin D in the general population of Estonia, a Northern European country. BMC Public Health 2009;9:22. https://doi. org/10.1186/1471-2458-9-22

8. Snellman G, Melhus H, Gedeborg R, et al. Seasonal genetic influence on serum 25-hydroxyvitamin D levels: A twin study. PLoS One 2009;4(11):e7747. https://doi.org/10.1371/journal.pone.0007747

9. Bogh MK, Schmedes AV, Philipsen PA, Thieden E, Wulf HC. Vitamin D production after UVB exposure depends on baseline vitamin $\mathrm{D}$ and total cholesterol but not on skin pigmentation. J Invest Dermatol 2010;130(2):546-553. https://doi.org/10.1038/jid.2009.323

10. Ackerman WT, Kwiek JJ. Role of the placenta in adverse perinatal outcomes among HIV-1 seropositive women. J Nippon Med Sch 2013;80(2):90-94. https://doi.org/10.1272/jnms.80.90

11. National Department of Health, South Africa. The National Antenatal Sentinel HIV and Syphilis National Department of Health, South Africa. The National Antenatal Sentinel HIV and Syphilis
Prevalence Survey, South Africa. 2011. https://www.hst.org.za/publications/NonHST\%20Publications/ Prevalence Survey, South Africa. 2011. https://www.hst.org.za/publications/Non
Antenatal_Sentinel_survey_Report2012_final.pdf (accessed 5 September 2019).

12. Institute of Medicine. Dietary Reference Intakes for Calcium and Vitamin D. Washington, DC: National Academies Press, 2011

13. Ranchod H, Thandrayen K, Pettifor JM. Vitamin D status of mothers and their newborns in Soweto. In: Oral Presentations, 14th Congress of NOFSA, 2010, Durban. J Endocrinol Metab Diabetes S Afr 2010;15(1):40.

14. George JA, Norris SA, van Deventer HE, Pettifor JM, Crowther NJ. Effect of adiposity, season, diet and calcium or vitamin D supplementation on the vitamin D status of healthy urban African and AsianIndian adults. Br J Nutr 2014;112(4):590-599. https://doi.org/10.1017/S0007114514001202

15. Bodnar LM, Simhan HN, Powers RW, Frank MP, Cooperstein E, Roberts JM. High prevalence of vitamin D insufficiency in black and white pregnant women residing in the northern United States and their neonates. J Nutr 2007;137(2):447-452. https://doi.org/10.1093/jn/137.2.447

16. Burris HH, Rifas-Shiman SL, Camargo CA, et al. Plasma 25-hydroxyvitamin D during pregnancy and small-for-gestational age in black and white infants. Ann Epidemiol 2012;22(8):581-586. https://doi. small-for-gestational age in black and
org/10.1016/.annepidem.2012.04.015

17. Wegienka G, Kaur H, Sangha R, Cassidy-Bushrow AE. Maternal-cord blood vitamin D correlations vary Wegienka G, Kaur H, Sangha R, Cassidy-Bushrow AE. Maternal-cord blood vitamin D co
by maternal levels. J Pregnancy 2016;2016:7474192. https://doi.org/10.1155/2016/7474192

18. Choi R, Kim S, Yoo H, et al. High prevalence of vitamin D deficiency in pregnant Korean women: The Choi R, Kim S, Yoo H, et al. High prevalence of vitamin D deficiency in pregnant Korean women: The
first trimester and the winter season as risk factors for vitamin D deficiency. Nutrients 2015;7(5):34273448. https://doi.org/10.3390/nu7053427

19. Okonofua F, Houlder S, Bell J, Dandona P. Vitamin D nutrition in pregnant Nigerian women at term and their newborn infants. J Clin Pathol 1986;39(6):650-653. https://doi.org/10.1136/jcp.39.6.650

20. Luxwolda MF, Kuipers RS, Kema IP, van der Veer E, Dijck-Brouwer DA, Muskiet FA. Vitamin D status indicators in indigenous populations in East Africa. Eur J Nutr 2013;52(3):1115-1125. https://doi. org/10.1007/s00394-012-0421-6

21. Durazo-Arvizu RA, Camacho P, Bovet P, et al. 25-hydroxyvitamin D in African-origin populations at varying latitudes challenges the construct of a physiologic norm. Am J Clin Nutr 2014;100(3):908-914. https://doi.org/10.3945/ajcn.113.066605

22. Toko EN, Sumba OP, Daud II, et al. Maternal vitamin D status and adverse birth outcomes in children from rural Western Kenya. Nutrients 2016;8(12). https://doi.org/10.3390/nu8120794
23. Nicolaidou P, Hatzistamatiou Z, Papadopoulou A, et al. Low vitamin D status in mother-newborn pairs in Greece. Calcif Tissue Int 2006; 78(6):337-342. https://doi.org/10.1007/s00223-006-0007-5

24. Brot C, Vestergaard P, Kolthoff N, Gram J, Hermann AP, Sorensen OH. Vitamin D status and its adequacy in healthy Danish perimenopausal women: Relationships to dietary intake, sun exposure and serum parathyroid hormone. Br J Nutr 2001;86(Suppl 1):S97-S103. https://doi.org/10.1079/BJN2001345

25. Rockell JE, Green TJ, Skeaff CM, et al. Season and ethnicity are determinants of serum 25 -hydroxyvitamin D concentrations in New Zealand children aged 5 - 14 y. J Nutr 2005;135(11):2602-2608. https://doi. org/10.1093/jn/135.11.2602

26. Grant CC, Wall CR, Crengle S, Scragg R. Vitamin D deficiency in early childhood: Prevalent in the sunny South Pacific. Public Health Nutr 2009;12(10):1893-1901. https://doi.org/10.1017/S1368980009004820

27. Thomas SD, Fudge AN, Whiting M, Coates PS. The correlation between third-trimester maternal and newborn-serum 25-hydroxy-vitamin D in a selected South Australian group of newborn samples. BM] Open 2011;1(2):e000236. https://doi.org/10.1136/bmjopen-2011-000236

28. Dawodu A, Saadi HF, Bekdache G, Javed Y, Altaye M, Hollis BW. Randomized controlled trial (RCT) of vitamin D supplementation in pregnancy in a population with endemic vitamin D deficiency. J Clin of vitamin D supplementation in pregnancy in a population with endemic vita
Endocrinol Metab 2013:98(6):2337-2346. https://doi.org/10.1210/jc.2013-1154

29. Song SJ, Si S, Liu J, et al. Vitamin D status in Chinese pregnant women and their newborns in Beijin and their relationships to birth size. Public Health Nutr 2013;16(4):687-692. https://doi.org/10.1017/ S1368980012003084

30. Yu CK, Sykes L, Sethi M, Teoh TG, Robinson S. Vitamin D deficiency and supplementation during pregnancy. Clin Endocrinol (Oxf) 2009;70(5):685-690. https://doi.org/10.1111/j.1365-2265.2008.03403.x 31. Basile LA, Taylor SN, Wagner CL, Quinones L, Hollis BW. Neonatal vitamin D status at birth at latitude 32 degrees 72': Evidence of deficiency. J Perinatol 2007;27(9):568-571. https://doi.org/10.1038/sj.jp.7211796

32. Cadario F, Savastio S, Pozzi E, et al. Vitamin D status in cord blood and newborns: Ethnic differences. Ital J Pediatr 2013;39:35. https://doi.org/10.1186/1824-7288-39-35

33. Eichholzer M, Platz EA, Bienstock JL, et al. Racial variation in vitamin D cord blood concentration in white and black male neonates. Cancer Causes Control 2013;24(1):91-98. https://doi.org/10.1007/ s10552-012-0093-9

34. Bowyer L, Catling-Paull C, Diamond T, Homer C, Davis G, Craig ME. Vitamin D, PTH and calcium levels in pregnant women and their neonates. Clin Endocrinol (Oxf) 2009;70(3):372-377. https://doi org/10.1111/j.1365-2265.2008.03316.x

35. Newhook LA, Sloka S, Grant M, Randell E, Kovacs CS, Twells LK. Vitamin D insufficiency common in newborns, children and pregnant women living in Newfoundland and Labrador, Canada. Matern Child Nutr 2009;5(2):186-191. https://doi.org/10.1111/j.1740-8709.2008.00157.x

36. Yayla AC, Kurek EM, Turan I, Ozkaya E, Pekin O, Karateke A. Association between maternal circulating 25 hydroxyvitamin D concentration and placental volume in the first trimester. J Matern Fetal Neonatal Med 2017;30(24):2944-2950. https://doi.org/10.1080/14767058.2016.1269315

37. Gernand AD, Simhan HN, Klebanoff MA, Bodnar LM. Maternal serum 25-hydroxyvitamin D and measures of newborn and placental weight in a U.S. multicenter cohort study. J Clin Endocrinol Metab 2013;98(1):398-404. https://doi.org/10.1210/jc.2012-3275

38. Wang $\mathrm{H}$, Xiao $\mathrm{Y}$, Zhang L, Gao Q. Maternal early pregnancy vitamin D status in relation to low birth weight and small-for-gestational-age offspring. J Steroid Biochem Mol Biol 2018;175:146-150. https:/ doi.org/10.1016/j.jsbmb.2017.09.010

39. Wei SQ, Audibert F, Luo ZC, et al. Maternal plasma 25-hydroxyvitamin D levels, angiogenic factors, and preeclampsia. Am J Obstet Gynecol 2013;208(5): 390.el-390.e6. https://doi.org/10.1016/j. ajog.2013.03.025

40. Lechtermann C, Hauffa BP, Herrmann R, et al. Maternal vitamin D status in preeclampsia: Seasona changes are not influenced by placental gene expression of vitamin D metabolizing enzymes. PLoS One 2014;9(8):e105558. https://doi.org/10.1371/journal.pone.0105558

41. Alvarez-Fernandez I, Prieto B, Rodriguez V, Ruano Y, Escudero AI, Alvarez FV. Role of vitamin D and sFlt-1/PlGF ratio in the development of early- and late-onset preeclampsia. Clin Chem Lab Med 2015;53(7):1033-1040. https://doi.org/10.1515/cclm-2014-1039

42. Brocklehurst $\mathrm{P}$, French R. The association between maternal HIV infection and perinatal outcome A systematic review of the literature and meta-analysis. Br J Obstet Gynaecol 1998;105(8):836-848 https://doi.org/10.1111/j.1471-0528.1998.tb10227.x

43. Kim JH, Gandhi V, Psevdos G Jr, Espinoza F, Park J, Sharp V. Evaluation of vitamin D levels amon HIV-infected patients in New York City. AIDS Res Hum Retroviruses 2012;28(3):235-241. https://doi org/10.1089/aid.2011.0040

44. Rutstein R, Downes A, Zemel B, Schall J, Stallings V. Vitamin D status in children and young adult with perinatally acquired HIV infection. Clin Nutr 2011;30(5):624-628. https://doi.org/10.1016/ clnu.2011.02.005

45. Stein EM, Yin MT, McMahon DJ, et al. Vitamin D deficiency in HIV-infected postmenopausal Hispanic and African-American women. Osteoporos Int 2011;22(2):477-487. https://doi.org/10.1007/s00198-010$1299-\mathrm{x}$

46. Wasserman P, Rubin DS. Highly prevalent vitamin D deficiency and insufficiency in an urban cohor of HIV-infected men under care. AIDS Patient Care STDS 2010;24(4):223-227. https://doi.org/10.1089/ apc.2009.0241

47. Rodriguez M, Daniels B, Gunawardene S, Robbins GK. High frequency of vitamin D deficiency in ambulatory HIV-positive patients. AIDS Res Hum Retroviruses 2009;25(1):9-14. https://doi.org/10.1089/ aid.2008.0183

48. Cervero M, Agud JL, Torres R, et al. Higher vitamin D levels in HIV-infected out-patients on treatmen with boosted protease inhibitor monotherapy. HIV Med 2013;14(9):556-562. https://doi.org/10.1111/ hiv.12049

49. Cervero M, Agud JL, Garcia-Lacalle C, et al. Prevalence of vitamin D deficiency and its related risk factor in a Spanish cohort of adult HIV-infected patients: Effects of antiretroviral therapy. AIDS Res Hum Retroviruses 2012;28(9):963-971. https://doi.org/10.1089/AID.2011.0244

50. Munns CF, Shaw N, Kiely M, et al. Global Consensus Recommendations on Prevention and Management of Nutritional Rickets. J Clin Endocrinol Metab 2016;101(2):394-415. https://doi.org/10.1210/jc.20152175

51. Curtis EM, Moon RJ, Harvey NC, Cooper C. Maternal vitamin D supplementation during pregnancy Br Med Bull 2018;126(1):57-77. https://doi.org/10.1093/bmb/ldy010

Accepted 3 April 2019 